\section{THE BARN OWL IN ALBERTA}

by Wayne Smith, 8220 Elbow Drive, Calgary

On the weekend of July 22-23, 1967, Cleve Wershler and I were in the Cypress Hills at Elkwater. At 10:20 p.m. on July 22, while listening for night birds, we heard a bird we couldn't identify. Twice we plunged through the thick brush at the southwest corner of the Elkwater Lake campsite, but only had one glimpse of the bird in our flashlights. We decided, from what we had glimpsed, that the bird was an owl; but what kind of owl?

At approximately $10: 35$ p.m., under a clear, moonlit sky, we tracked down the owl. It was sitting on top of a 15 -foot pole. We shone both our flashlights (one, a four-cell) on the owl. It was obviously a Barn Owl (Tyto alba).

We made a field description, writing down the following points: long legs, snowy-white underparts, long wings, heart-shaped face, and its size (about that of a small Great Horned Owl, roughly 18 inches). As we watched it from the bottom of the pole the Barn Owl kept calling (a magpie-like croak -nasal, wheezy and ascending) and it also kept lowering its head and weaving it from side to side. Each time it flew, its flight was moth-like. This particular pole must have been a favorite perch because it was reluctant to leave the pole and kept returning to it. Four times we observed the Barn Owl for over a full minute.

Twice, the Barn Owl we were watching was answered by another Barn Owl. Also, at about 1:00 a.m., July 23, we heard a long, quavering whistle from the east end of the campground. We read later in $\mathrm{A}$. C. Bent's "Life Histories" volume on owls that the call of a young Barn Owl with unopened eyes is "a highpitched quavering whine . . ." Egg dates for Barn Owls are reported as very unpredictable.

The Barn Owl is very scarce in the Prairie Provinces. Salt and Wilk
(Birds of Alberta) show no previous records for Alberta. Recent reports in the Blue Jay $(21: 104,25: 22)$ show the following: Saskatchewan, four records - Balcarres, May 1, 1910; Aylesbury, May 5, 1924; Kindersley, May 18, 1930; and Regina, May 3, 1936; Manitoba, four records - S.t. Anne's, November 6, 1912; Sperling, January 1925; Whitewater Lake, October 1927; and La Rivière, April 8, 1945 .

\section{ALBERTA INDIGO BUNTING RECORD}

by Wayne Smith, 8220 Elbow Drive, Calgary

On June 24, 1967, Garry McKay, Stu Alexander, Cleve Wershler, two small children and I were on a field trip along the eastern Rockies. We stopped by a small slough about 15 miles north of Kananaskis Lake, about 50 miles west of Calgary. In a large grove of young aspens we heard a bird song that none of us had ever heard before. After many minutes of stealthy stalking we managed to get a good look at the bird and identified it as a young male Indigo Bunting (Passerina cyanea). It was a deeper blue and smaller than a Mountain Bluebird, and its body shape and bill were distinctive. Its plumage contained a lot of grey mixed with the blue. We supposed it to be a nonbreeding young male as its territory seemed large and ill-defined.

Later on in the day we had an opportunity to compare its song, which we had carefully listened to, with Lazuli Bunting (Passerina amoena) songs, for we found about eight of the latter species about 15 miles west of Longview. Although Salt and Wilk (in Birds of Alberta, 1966) state that it is impossible to separate the species by voice, we found a distinct difference. While observing the Lazuli Buntings we briefly glimpsed a bunting whose song appeared to be that of an Indigo Bunting, and we felt fairly sure that it was this species. 
The Indigo Bunting is regarded as a "scarce summer resident" by Salt and Wilk, who list the following records: a male specimen from Lac La Nonne, June 3, 1926; a male seen near Elkwater Lake in the Cypress Hills, June 26, 1952; and specimens from Gorge Creek in the foothills west of Turner Valley, were apparently nesting along with Lazuli Buntings in 1958 and 1959.

\section{UNUSUAL FATAL ACCIDENT INVOLVING A LAPLAND LONGSPUR}

by Spencer G. Sealy, Department of Zoology, University of British Columbia, Vancouver, B.C.

A source of winter income for some Eskimos on St. Law rence Island, Alaska, is trapping arctic foxes (Alopex lagopus) (Hughes, An Eskimo Village in the Modern World, Cornell Univ. Press. 1960). One of the many types of bait used for this purpose is seal fat which is placed in and near the trap site, usually before the trapping season begins, and which is often left after trapping is over (Leroy Kulukhon, pers. comm., 1967). This note records an incident whereby a piece of seal blubber caused or contributed to the death of a Lapland Longspur (Calcarius lapponicus).

On July 19, 1967, a dead and ema-

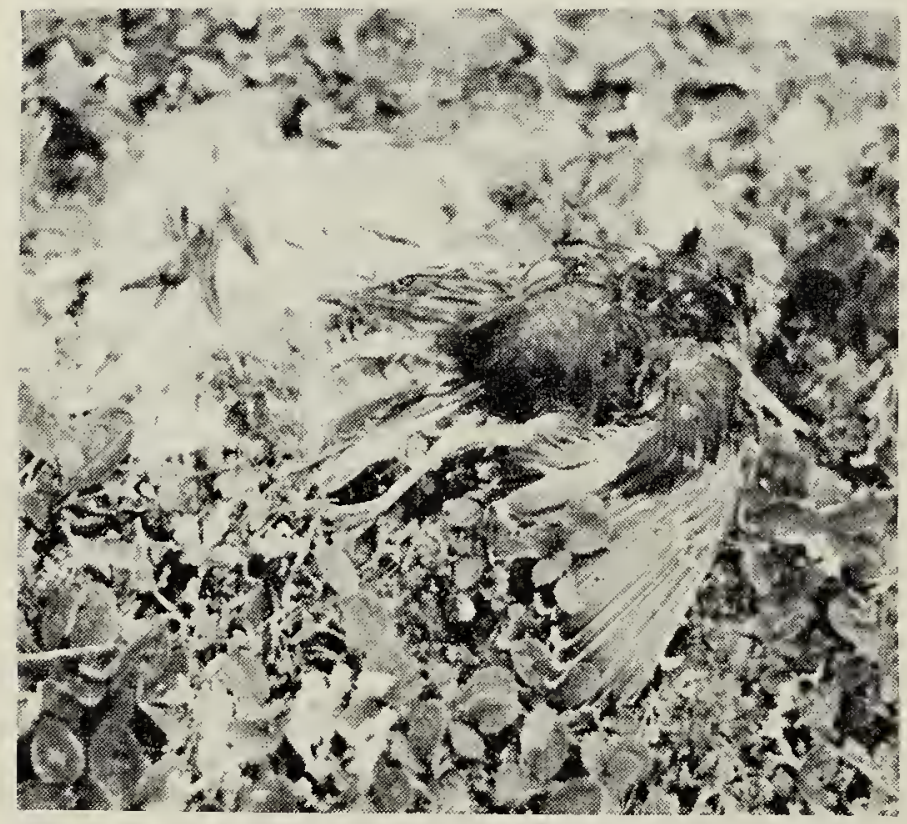

Fig. 1 - Dead and emaciated Lapland Longspur with its left leg s.tuck to a piece of seal blubber, St. Lawrence Island, Alaska, July 19, 1967. ciated Lapland Longspur, its age and sex undetermined, was found at the base of Sevuokuk Mountain, two miles east of Gambell. The bird's left foot was stuck solidly to a piece of seal blubber near an abandoned trap site amid dwarf willows (Salix) (Fig 1), common foraging areas for Lapland Longspurs at this date on S.t. Lawrence Island. The entanglement possibly resulted when the bird accidentally stepped on the fat while foraging or possibly it was attracted to insects on the fat. Insects constitute a large proportion of Lapland Longspur food at this time (Sealy, unpublished data).

Arctic breeding birds face many problems in the short summer; however, unique accidents like that described here probably form a negligible mortality factor. This observation was made while I was engaged in a comparative breeding biology study of the plankton-feeding alcids on St. Lawrence Island. The work was supported by a grant from the National Research Council of Canada to Dr. M. D. F. Udvardy.

\section{AN UNUSUAL GOLDFINCH MORTALITY}

by Ken P. Morrison, Oliver, B.C.

On August 18, 1967 while carrying out an ecology study of the Mourning Dove in the $\mathrm{Okanagan}$ valley of British Columbia, I discovered an unusual incidence of nest mortality in the American Goldfinch (Spinus tristis).

During my routine dove nest search I noticed a small, compact nest 10 feet up in a peach tree in an Oliver orchard. Closer inspection revealed a dead juvenile Goldfinch hanging from the edge of the nest with both feet securely entangled in the plant fiber of the inner lining. The bird had struggled in vain as attested by the frayed and worn feathers of the wings and tail where they had been beaten on the branches supporting the nest. The cause of death was probably due to starvation. The other nestlings appear to have fledged without diffi- 